\title{
АДАПТАЦІЯ ДІТЕЙ ДО ШКОЛИ З ЗАТРИМКОЮ ПСИХІЧНОГО РОЗВИТКУ
}

Стаття присвячена особливостям адаптаиії дітей до школи з затримкою психічного розвитку. Здійснено спробу розкрити сутність понять: адаптації, ї̈ рівнів та відповідних їм рівнів здібностей, і порівняння факторів адаптаиії дітей з нормальних нервово - психічним розвитком $i$ дітей з ЗПР. Висвітленні основні механізми, які впливають на дезадаптацію дітей з ЗПР, йх

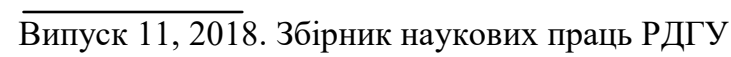


особливості протікання, механізми активної діяльності індивіда. Вказано, на взаємозалежність діяльності батьків і педагогів, на формування продуктивної шкільної адаптаиії дітей з ЗПР, та побудову позитивного досвіду через активний розвиток творчих здібностей $і$ не традиційних схем мислення.

Ключові слова: адаптація, сочіальна адаптачія, затримка психічного розвитку, соматичне благополуччя, емоиійна прив'язаність, інтелектуальний розвиток, депривація, соиіально особистісний розвиток.

Статья посвящена особенностям адаптации детей к школе с задержкой психического развития. Предпринята попытка раскрыть сущность понятий: адаптации, ее уровней и соответствующих им уровней способностей, и сравнение факторов адаптации детей с нормальным нервно - психическим развитием и детей с ЗПР. Рассмотрены основные механизмы, влияюшие на дезадаптацию детей с ЗПР, их особенности протекания, механизмы активной деятельности индивида. Указано на взаимозависимость деятельности родителей и педагогов, и формирование продуктивной школьной адаптации детей с ЗПР, и построение положительного опыта, через активное развитие творческих способностей и не традичионных схем мышиения.

Ключевые слова: адаптаџия, сочиальная адаптаџия, задержка психического развития, соматическое благополучие, эмочиональная привязанность, интеллектуальное развитие, депривачия, социально - личностное развитие.

Постановка проблеми. В умовах нестабільної соціально-економічної обстановки, багато дослідників (Б.М. Алмазов, О.С Батуєв, С.О. Белічева, І.А. Коробейніков та ін.) відзначають збільшення кількості учнів, які виявляються не в змозі освоїти навчальну програму за відведений час. За даними різних досліджень, від 15 до 40\% учнів початкових класів відчувають труднощі в навчанні. На етапі випуску з навчального закладу лише $10 \%$ випускників можуть вважатися здоровими, а 40$50 \%$ випускників школи за час навчання придбали певну хронічну патологію. Останнім часом відзначається чітка тенденція до погіршення психічного і психосоматичного здоров'я дітей та підлітків. Причому, зростання нервово-психічних і соматичних захворювань, різних функціональних розладів пов'язане із загальним зниженням успішності. Як показують дослідження, серед невстигаючих школярів приблизно 40\% складають діти із затримкою психічного розвитку (ЗПР) [5]. Попри достатню теоретичну розробленість даної проблеми і створену вітчизняними дефектологами систему спеціальної допомоги подібним дітям, процес інтеграції дітей з ЗПР в суспільство пов'язаний 3 певними труднощами. Зокрема, у таких дітей виникають складності в процесі шкільної та професійної адаптації. Незважаючи на корекційну спрямованість спеціальних (корекційних) класів $\mathrm{i}$ шкіл для дітей з ЗПР, завдання соціальної адаптації подібного дитини вирішується далеко не завжди успішно.

Все вищесказане вимагає пильної уваги до дітей з інтелектуальною недостатністю, зміщення акценту в роботі з інтелектуальної недостатності такої дитини на його особистісний розвиток, а також розробки конкретних заходів профілактики і корекції відхилень у розвитку дитини з ЗПР, оскільки саме школа і педагоги повинні відігравати вирішальну роль, як в діагностиці, так і в профілактиці порушень психічного і психосоматичного розвитку дітей [6]. Недостатність якісної методологічної та практичної розробки системи надання спеціальної допомоги дітям з ЗПР, і відсутність загальноприйнятих підходів до навчання і виховання дітей з ЗПР з урахуванням їх психологічних особливостей зумовило вибір теми дослідження.

Аналіз останніх досліджень и публікацій. Проблемам дітей з ЗПР присвячений ряд досліджень (Т. А. Власова, М. С. Певзнер, Л.М. Шипіцин, Т.В. Єгорова, Р.М. Лалаєва, Л.С. Волкова; О.В. Лебедєва, І.Ф. Марковська і ін.)

Формулювання цілей статті:

1. Розкрити сутність понять: адаптація і затримка психічного розвитку.

2. Вказати на особливості шкільної дезадаптації дітей з затримкою психічного розвитку.

3. Вивчити закономірності розвитку особистісних якостей дітей з затримкою психічного розвитку.

4. Провести порівняльний аналіз факторів адаптації дітей з ЗПР і з нормальним нервово психічним розвитком.

Виклад основного матеріалу дослідження. Затримка психічного розвитку характеризується недостатнім рівнем розвитку моторики, мови, уваги, пам'яті, мислення, регуляції і саморегуляції поведінки, примітивністю і нестійкістю емоцій, поганою успішністю в школі. Діти із затримкою 
психічного розвитку потребують спеціально організованого корекційно-розвиваючого навчання та медичного супроводу [5].

Затримка психічного розвитку (ЗПР) являє собою зворотні порушення інтелектуальної та емоційно-вольової сфери, що супроводжуються специфічними труднощами в навчанні. ЗПР $є$ більшою мірою психолого-педагогічної категорією, проте в іiі основі можуть лежати органічні порушення, тому даний стан також розглядається медичними дисциплінами - перш за все, педіатрією i дитячою неврологією. Оскільки розвиток різних психічних функцій у дітей відбувається нерівномірно, зазвичай висновок «затримка психічного розвитку» встановлюється дітямдошкільнятам не раніше 4-5 років, а на практиці - частіше в процесі шкільного навчання. Етіологічну основу ЗПР становлять біологічні та соціально-психологічні чинники, що призводять до темпової затримки інтелектуального і емоційного розвитку дитини [6]. Затримка психічного розвитку вторинного характеру може розвиватися при ранніх порушеннях слуху та зору, дефекти мови внаслідок вираженого дефіциту сенсорної інформації і спілкування. Саме такі особливості життя і розвитку дитини часто стають причинами шкільної дезатаптації таких дітей і адаптації в цілому [2].

Проблему адаптації вперше підняв в науці Ж.-Б. Ламарк, який пов'язував еволюційні зміни окремих організмів з пристосуванням їх до навколишнього середовища. Він вважав, що зміни організму, викликані цим пристосуванням закріплюються і передаються спадково, за умови, якщо придбані адаптивні зміни притаманні обом статям, яка дала потомство. Згодом термін «адаптація» став використовуватися в фізіології, він означав пристосувальні зміни кожних аналізаторів до дій зовнішніх подразників ( $Г$. Ауберт). На початку $\mathrm{XX}$ ст. значення слова «адаптація» стало розширюватися і включати крім фізіологічних і біологічних процесів також і процес пристосування особистості до соціальних і культурних факторів навколишнього середовища.

Однак, незважаючи на досить давню історію вивчення, поняття «адаптація» трактується представниками різних наукових шкіл зовсім по-різному:

- $\quad$ як процес пристосування організму до різноманітних змін середовища (позитивного або негативного властивості);

- $\quad$ стан гомеостатичної, динамічної рівноваги між організмом і середовищем;

- результат оптимальної взаємодії між організмом і середовищем;

- гедоністична мета, яка полягає в пошуку насолоди, способи уникнути страждань, больових відчуттів і т. д.

Все різноманіття тлумачень, на думку М. В. Ромма, можна звести до двох парадигм: «нормативної» і «інтерпретативної». «Нормативна» парадигма виникла в соціології, вона розглядає соціальну адаптацію, як процес поступового «приближення» індивіда до норм суспільного життя. Завдяки контролю з боку суспільства індивіду «нав'язуються» правила і норми соціальної поведінки. Таким чином, індивід виступає в якості об'єкта суспільних маніпуляцій і адаптація фактично ототожнюється з процесом соціалізації. «Інтерпретативна» парадигма передбачає, що центр уваги переміщується на суб'єкта, який інтерпретуючи навколишню ситуацію активно шукає способи задоволення своїх потреб. Можна сказати, що таке тлумаченя більш психологічне, воно орієнтує дослідника на вивчення особливостей когнітивної сфери суб'єкта та факторів соціальної і предметно - діяльнісної ситуації. Соціалізація і адаптація при такому підході мають різні масштаби розгляду: соціалізація порівнюється з простором усього життя людини в соціумі, має «стратегічний» характер, а адаптація порівнянна з простором соціальної ситуації і має «тактичний» характер [1].

«Інтерпретативна» парадигма має для нас велику цінність, так як вона дозволяє розглядати індивіда, його переживання і способи задоволення потреб в процесі «входження» в нову для нього соціальну ситуацію. При цьому можна сказати, що індивід знаходиться в ситуації високого ступеня невизначеності, так як він ще не знає, як будуть задовольнятися його потреби. Можна припустити, що така ситуація провокує у суб'єкта стан тривоги і може гальмувати його активність. При цьому інтерпретація соціальної ситуації може залежати від когнітивних здатностей індивіда і суб'єктивного досвіду (позитивного або негативного) входження в подібні ситуації.

Соціальна ситуація, в яку «входить» дитина з нашої точки зору має складний багаторівневий характер. Порівнюючи, суб'єктивні чинники, що виникають в процесі «входження» іiі в нову соціальну обстановку, наприклад: дитячий садок, як одну з перших інстанцій, і соціальних груп в яку потрапляє дитина, після соціального інституту - сім'ї, у дітей з різними когнітивними можливостями, а саме дітей із затримкою психічного розвитку та дітей, які нормально розвиваються. І враховуючи, те що, для них це перший досвід входження в новий соціальний колектив, можна виділити декілька рівнів аналізу соціальної ситуації та рівнів адаптації. Нижчий соціально-психологічний рівень адаптації можна назвати просторово-предметним, оскільки він забезпечує адаптацію до просторових характеристик оточуючих предметів і об'єктів. Оточуючих людей дитина, що адаптується на цьому 
рівні, сприймає також, як і будь-який неживий предмет навколо [4]. Другий рівень адаптації комунікативно-симбіотичний, він передбачає пристосовування до дій інших людей і здатність вибудовувати з ними відносини взаємодії. При цьому дитина може проявляти активність тільки по відношенню до знайомих йому дорослим. Контакти з незнайомими людьми вона ігнорує, не бажаючи вступати з ними у взаємодію. Третій рівень адаптації можна назвати діяльністно-маніпулятивний, так як він передбачає врахування різних умов при реалізації предметних дій. Цей рівень передбачає активність суб'єкта і здатність використовувати інших людей для реалізації своїх планів. Фактично інші люди для суб'єкта, який адаптувався на цьому рівні, це об'єкти маніпулювання. Четвертий рівень - соціально-символічний, означає здатність розуміти соціальну символіку, а значить сутність вчинків, що, в свою чергу, дозволяє передбачити поведінку інших людей. Таким чином, головним показником цього рівня є бажання зрозуміти сенс поведінки оточуючих людей [4].

Кожному рівню адаптації відповідає і певна система потреб особистості. 1. Потреба в безпеці, зумовлює загальну загальмованість (через небажання привертати до себе увагу) або пасивний пошук найбільш безпечного місця перебування. 2. Соціальні потреби, пов'язані з потребами в спілкуванні, емоційними симбіотичними прихильностями. 3. Діяльнісні потреби, такі як бажання активно діяти, продовжувати почату дію, пізнавати навколишній світ і простір власного тіла, дізнатися функціональні можливості і властивості оточуючих предметів. 4. Соціально-культурні потреби, пов'язані з пізнанням символіки культури, цивілізаційних нормативів.

Провідним фактором, що визначає процес соціальної адаптації дітей з ЗПР 3-6 років, є переживання соматичного неблагополуччя. Пояснити цей факт можна тим, що соматичне неблагополуччя загострює чутливість дитини до деривацій iï потреб і знижує соціальну чутливість, що погіршує процес іії соціальної адаптації [3]. Іншими словами, хворобливі переживання, почуття тривоги і страху не дозволяють дитині з ЗПР об'єктивно оцінити навколишню обстановку і сприяють редукції поведінкових стратегій до дитячих форм, що веде до підвищення залежності дитини від дорослих. Системи міжособистісних відносин дитини, які в істотній мірі визначають надалі можливості самореалізації в шкільному середовищі і соціалізації в суспільстві починають формуватися в перші місяці, коли дитина потрапляє до школи. Те, яким шляхом піде розвиток школяра, чи буде він адекватно адаптований, чи сформується фундамент його подальшого навчання, багато в чому залежить від батьків, педагогів, вихователів та психолога школи.

У дітей 6-7 років із затримкою психічного розвитку, як правило, зберігаються стійкі прояви гармонійного інфантилізму, наслідком чого стає недостатня готовність до навчання в школі, відсутність інтересу до навчання, шкільна неуспішність і дезадаптація. У дезадаптованих до навчального середовища дітей з ЗПР часто зустрічається синдром гіперактивності, для якого характерні - загальне рухове занепокоєння, непосидючість, велика кількість зайвих рухів, імпульсивність, підвищена збудливість. Такі діти погано підкоряються дисциплінарним вимогам, у них виникають проблеми в спілкуванні з однолітками через агресивну поведінку. Все це призводить до вираженої шкільної дезадаптації [7]. Відомо, що в найпоширенішому своєму значенні шкільна адаптація розуміється як пристосування дитини до нової системи соціальних умов, нових стосунків, вимогам, режиму життєдіяльності і т. д. У школі, на етапах адаптації дитина з ЗПР може зіткнутися з низкою проблем: проблема розуміння вимог вчителів, дотримання правил поведінки в класі, далеко не всім дітям з ЗПР зрозумілий сенс ритуалу вставати на початку уроку, вставати, якщо увійшов інший учитель і так далі [3].

Варто зазначити, що для соціально-особистісного та соціально-комунікативного розвитку може допомогти стимулювання творчих здібностей у дітей, що допомагають створенню нових ідей, які відхиляються від традиційних схем мислення. Сьогодні особливий попит на всебічно і гармонійно розвинених, творчих і заповзятливих людей. Так, нашим завданням стає навчити сучасну дитину вчитися самостійно, знаходити взаємозв'язки, узагальнювати і аналізувати. Бачити ситуацію ширше i глибше, вміючи думати нестандартно. А придбати дані вміння діти з ЗПР можуть через спільну і персональну творчість. Якщо у дитини з'явилося нове вміння, важливо знайти йому застосування в реальному житті, найпростіше в класі, через виконання спільних 3 іншими дітьми завдань, де успішність виконання готового продукту буде частково залежати від дитини. Важливо дати дитині усвідомити, що люди роблять внесок у загальну справу, інвестуючи і в своє майбутнє.

Висновки 3 даного дослідження і перспективи подальших розвідок. Затримка психічного розвитку (ЗПР) являє собою зворотні порушення інтелектуальної та емоційно-вольової сфери, що супроводжуються специфічними труднощами в навчанні. Затримка психічного розвитку може виникати під впливом середовищних (соціальних) факторів, що однак не виключає наявність початкової органічної основи порушення. Такі особливості життя і розвитку дитини часто стають причинами шкільної дезатаптації таких дітей і адаптації в цілому. Поняття «адаптація» трактується як 
процес пристосування організму до різноманітних змін середовища. Соціальну адаптацію: процес поступового «приближення» індивіда до норм суспільного життя. Соціальна ситуація, в яку «входить» дитина має складний багаторівневий характер,а кожному рівню адаптації повинен відповідати і ведучий рівень здібностей. Провідним фактором, що визначає процес соціальної адаптації дітей з 3ПР 3-6 років, являється переживання соматичного неблагополуччя [5].

У дітей 6 - 7 років із затримкою психічного розвитку, переважно зберігаються стійкі прояви гармонійного інфантилізму, наслідком чого стає недостатня готовність до навчання в школі, відсутність інтересу до навчання, шкільна неуспішність і дезадаптація. Для соціально-особистісного та соціально-комунікативного розвитку може допомогти стимулювання у дітей творчих здібностей.

\section{Список використаних джерел}

1. Дика Л. Г. Адаптація: методологічні проблеми та основні напрямки досліджень / Л. Г. Дика // Психологія адаптації і соціальне середовище: сучасні підходи, проблеми, перспективи. - 2007. C. $17-42$.

2. Защиринська О. В. Психологія дітей із затримкою психічного розвитку / О. В. Защиринська. - Київ : Мова, 2007. - 168 с.

3. Ташина Т. М. Психолого-акмеологические предпосылки продуктивного развития младших школьников с трудностями в обучении : автореф. дис. ... канд. психол. наук / Т. М. Ташина. Кострома, 2010. - 23 с.

4. Ткачова В. В. Технологии психологической помощи семьям детей с отклонениями в развитии / В. В. Ткачова. - М. : АСТ, 2007. -318 с.

5. Семенов А. А. Работа с детьми группы риска: некоторые технологические приемы / А. А. Семенов // Социальная педагогика. - 2008. - № 6. - С. 41-45.

6. Шамарина Е. В. Обучение детей с ЗПР: организация индивидуальных и групповых занятий в классе коррекционно-развивающего обучения / Е. В. Шамарина. - М. : ГНОВ и Д, 2003. - 80 с.

7. Шипицын Л. М. Психологическая диагностика отклонений развития детей младшего школьного возраста / Л. М. Шипицын. - Питер, 2008. - 92 с.

\section{References}

1. Dikaya L. G. Adaptatsiya: metodologicheskiye problemy i osnovnye napravleniya issledovaniy / L. G. Dikaya // Psikhologiya adaptatsii i sotsialnaya sreda: sovremennye podkhody, problemy, perspektivy. M. : In-te of Psychology of Russian Academy of Sciences Publ., 2007. - P. 17-42.

2. Zashchirinskaya O. V. Psikhologiya detey $\mathrm{s}$ zaderzhkoy psikhicheskogo razvitiya / O. V. Zashchirinskaya. - SPb. : Rech Publ., 2007. - 168 p.

3. Tashina T. M. Psikhologo-akmeologicheskiye predposylki produktivnogo razvitiya mladshykh shkolnikov s trudnostyami obucheniya : avtoref. dis. ... kandid. psikhol. nauk / T. M. Tashina. - Kostroma : Kostroma State Un-ty named after N. A. Nekrasov Publ., 2010. - 23 p.

4. Tkacheva V. V. Tekhnologii psikhologicheskoy pomoshchi semyam detey s otkloneniyami v razvitii / V. V. Tkacheva. - M. : AST Publ., 2007. -318 p.

5. Semenov A. A. Rabota s detmi gruppy riska: nekotorye tekhnologicheskiye priemy / A. A. Semenov // Sotsialnaya pedagogika. - 2008, - № 6. - P. 41-45.

6. Shamarina Ye. V. Obucheniye detey s ZPR: organizatsiya individualnykh i gruppovykh zanyatiy v klasse korrektsionno-razvivayushchego obucheniya / Ye. V. Shamarina. - M. : GNOM i D Publ., 2003. $80 \mathrm{p}$.

7. Shipitsyna L. M. Psikhologicheskaya diagnostika otkloneniy razvitiya detey mladshego shkolnogo vozrasta / L. M. Shipitsyna. - SPb. : Rech Publ., 2008. - 92 p.

\section{RETARDATION \\ T.V.Shcerba THE ADAPTATION OF CHILDREN TO SCHOOL WITH MENTAL}

The article is devoted to the peculiarities of the adaptation of children to a school with a mental retardation. The author considers the concept of adaptation as a process of adapting the organism to various changes in the environment and defines the leading factor - the experience of somatic distress, which determines the process of social adaptation of children with mental retardation.

The article states that the delay of mental development is a reverse violation of the intellectual and emotional-volitional sphere, accompanied by specific difficulties in learning. Delay in mental development can occur under the influence of environmental (social) factors, which, however, does not exclude the 
presence of the initial organic basis of the violation. Such peculiarities of the child's life and development often become the causes of school distaptation of such children and adaptation in general.

The author attempts to reveal the essence of concepts: adaptation, its levels and their respective levels of abilities, and a comparison of the factors of adaptation of children from normal neuropsychiatric development and children with mental retardation. In the work it is define the main peculiarities that influence on the disadaptation of children with mental retardation, their peculiarities of flow, and the mechanisms of active activity of the individual. The author points out the interdependence of the activities of parents and teachers, the formation of productive school adaptation of children with mental retardation, and the building of positive experience through the active development of creative abilities and not traditional patterns of thinking.

Key words: adaptation, social adaptation, mental retardation, somatic well - being, emotional attachment, intellectual development, deprivation, social and personal development. 